\title{
PREDIKSI JUMLAH PEMBERIAN KREDIT KEPADA NASABAH DI BANK PERKREDITAN RAKYAT DENGAN ALGORITMA C 4.5
}

\author{
Eka Praja Wiyata Mandala, Dewi Eka Putri \\ Universitas Putra Indonesia YPTK Padang, Indonesia \\ E-mail: ekaprajawm@upiyptk.ac.id, dewieka@upiyptk.ac.id
}

\begin{abstract}
Abstrak
Bank Perkreditan Rakyat adalah lembaga keuangan bank yang menerima simpanan hanya dalam bentuk deposito berjangka, tabungan, dan/atau bentuk lainnya yang dipersamakan dan menyalurkan dana sebagai usaha BPR. Masalah yang dialami BPR adalah pemberian kredit yang kurang tepat sasaran dan waktu tunggu keputusan nasabah yang lama. Maka dalam penelitian ini usulkan sebuah cara untuk memprediksi pemberian kredit yang dapat membantu pihak BPR dalam mengambil keputusan yang akurat dan tepat sasaran. Metode yang digunakan untuk melakukan prediksi tersebut adalah Algoritma C 4.5. Algoritma C 4.5 merupakan algoritma yang paling banyak digunakan untuk melakukan prediksi di dalam Data Mining. Jadi yang akan menjadi keputusan akhir dari prediksi pemberian kredit ini adalah keputusan besar atau kecilnya jumlah kredit yang akan diberikan kepada nasabah.
\end{abstract}

Kata kunci: Data Mining, Algoritma C 4.5, Prediksi, Bank Perkreditan Rakyat

\section{Pendahuluan}

Bank Perkreditan Rakyat adalah lembaga keuangan yang menghimpun dana dari masyarakat dalam bentuk simpanan dan menyalurkan kembali dalam bentuk kredit. Salah satu bentuk kredit yang dimiliki oleh Bank Perkreditan Rakyat adalah kredit Cicilan yang diperuntukan bagi nasabah baik itu legal maupun non legal dengan ketentuan digunakan sebagai solusi lengkap untuk nasabah yang ingin manambah modal atau memenuhi kebutuhan lainnya. Proses penilaian kelayakan pemberian kredit ini menjadi permasalahan pada Bank Perkreditan Rakyat.

Untuk proses persetujuan pemberian kredit tersebut Bank Perkreditan Rakyat harus melakukan analisis secara detail sehingga dapat ditentukan apakah kredit tersebut dapat disetujui atau tidak. Saat ini ada beberapa kendala dalam proses pemberian kredit di Bank Perkreditan Rakyat yaitu kurang tepatnya hasil keputusan yang bisa mengakibatkan kerugian dari Bank Perkreditan Rakyat itu sendiri, dan kurang cepat hasil analisis kredit yang dilakukan.

Hal tersebut dipengaruhi oleh faktor human error karena analisis kredit yang dilakukan oleh analis kredit selama ini masih menggunakan cara manual. Sedangkan data yang akan dianalisis jumlahnya puluhan bahkan ratusan perhari, sehingga mengakibatkan tingkat kesalahanan analisis sangat besar dan membutuhkan waktu yang lama. Oleh sebab itu, dibutuhkan solusi yang dapat membantu dalam pengambilan keputusan oleh analis kredit untuk mengatasi permasalahan tersebut.

Dari permasalahan diatas, dapat dirumuskan masalah dalam penelitian ini yaitu bagaimana data mining dapat membantu Bank Perkreditan Rakyat dalam melakukan analisis dan prediksi dalam pemberian kredit kepada nasabah mereka? 
Untuk menyelesaikan masalah diatas, maka akan diusulkan sebuah penelitian yang berhubungan dengan data mining dengan menggunakan Algoritma C 4.5 untuk melakukan prediksi dalam pemberian kredit di Bank Perkreditan Rakyat tersebut.

\section{Tinjauan Literatur}

\subsection{Data Mining}

Teknik data mining menggunakan statistik, kecerdasan buatan, dan pengenalan pola data untuk perilaku kelompok atau entitas. Dengan demikian, data mining adalah bidang interdisipliner yang mempekerjakan penggunaan alat analisis dari model statistik, algoritma matematika, dan metode pembelajaran mesin untuk menemukan yang sebelumnya tidak diketahui, pola dan hubungan yang valid dalam set data yang besar [2].

Proses data mining dimulai dengan mengekstraksi data yang kemudian menghasilkan sebuah informasi. Informasi yang dihasilkan kemudian diolah untuk menghasilkan biasa berbentuk pola (pattern). Pola inilah yang kemudian diterjemahkan menjadi sebuah pengetahuan. Dan pengetahuan yang dihasilkan dapat digunakan untuk mengambil keputusan oleh pimpinan dalam sebuah perusahaan [4].

Menurut Gartner Group, "Data Mining adalah suatu proses menemukan hubungan yang berarti, pola, dan kecenderungan dengan memeriksa dalam sekumpulan besar data yang tersimpan dalam penyimpanan dengan menggunakan teknik pengenalan pola seperti teknik statistik dan matematika [7]".

Data Mining adalah "proses yang menggunakan teknik statistik, matematika, kecerdasan buatan, dan machine learning untuk mengekstraksi dan mengidentifikasi informasi yang bermanfaat dan pengetahuan yang terakit dari berbagai database besar [10]".

Data Mining adalah "Melakukan ekstraksi untuk mendapatkan informasi penting yang sifatnya implisit dan sebelumnya tidak diketahui, dari suatu data [11]".

Data mining juga merupakan bagian dari proses Knowledge Discovery in Database (KDD). Proses KDD terdiri dari langkah-langkah berikut [6] :

1. Data cleaning, menghilangkan noise dan data yang tidak konsisten

2. Data integration, mengintegrasikan beberapa sumber data yang dapat digabungkan

3. Data selection, menyeleksi data yang relevan dengan tugas analisis akan diambil dari database

4. Data transformation, proses dimana data ditransformasikan atau dikonsolidasi dalam format yang sesuai untuk diproses dalam data mining

5. Data mining, sebuah proses esensial dimana metode diaplikasikan untuk mengekstrak pola data

6. Pattern evaluation, proses untuk mengidentifikasi pola-pola yang menarik untuk direpresentasikan ke dalam knowledge based

7. Knowledge Presentation, proses visualisasi dan teknik representasi pengetahuan yang digunakan untuk menyajikan pengetahuan yang berguna kepada pengguna

Menurut [9], proses KDD dapat digambarkan sebagai berikut : 


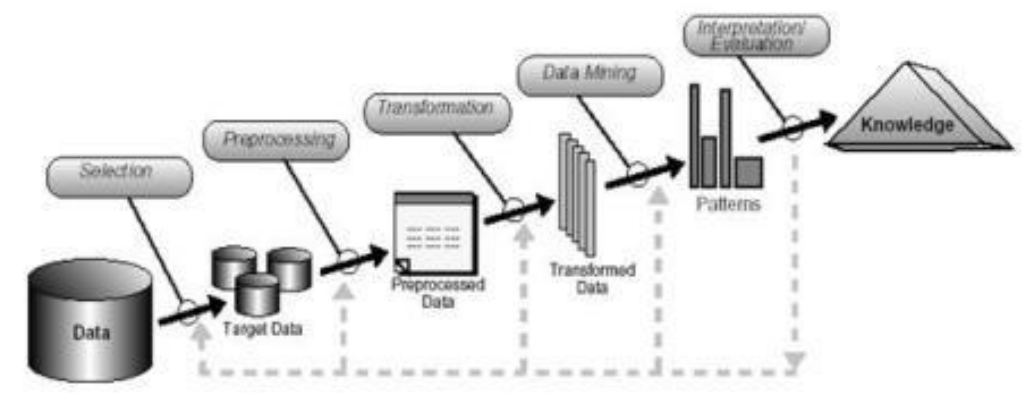

Gambar 1. Proses Knowledge Discovery in Database

KDD mengacu pada proses keseluruhan yang dilakukan untuk menemukan pengetahuan yang tersimpan dari data. Proses yang terjadi dalam KDD adalah sebagai berikut [12] :

a. Seleksi

Pada tahap ini dilakukan pemilihan data yang berguna dalam proses Data Mining untuk membantu mencari solusi masalah. Karena tidak semua data yang digali akan digunakan pada tahap ini.

b. Pra-pengolahan

Pada tahap ini dilakukan proses pra-pengolahan data, termasuk pembersihan data untuk menyingkirkan anomali dari data yang rrusak, hilang, maupun mengalami kesalahan.

c. Transformasi

Pada tahap ini dilakukan pengubahan tipe data agar sesuai dengan data yang digunakan untuk proses pengolahan.

d. Data Mining

Pada tahap ini diterapkan pemilihan teknik Data Mining yang sesuai dengan tujuan dan algoritma Data Mining untuk pencarian pola yang menarik.

e. Interpretasi/evaluasi

Pada tahap ini dilakukan visualisasi dan interpretasi terhadap pola yang ditemukan untuk dijadikan pengetahuan serta menghapus pola berlebihan dari yang telah dihasilkan. Pengetahuan membantu pengguna untuk memanfaatkan pengetahuan yang diperoleh untuk mengambil keputusan yang terbaik.

Salah satu contoh penerapan data mining adalah di bidang [1] Perbankan dan layanan keuangan yang merupakan salah satu area yang pertama dan paling penting untuk aplikasi data mining. Dengan demikian, dalam perbankan, metode data mining yang intensif digunakan (dan masih berhasil digunakan) dalam:

a. Pemodelan dan peramalan penipuan kredit;

b. Penilaian resiko;

c. Analisis kecenderungan;

d. Analisis profitabilitas;

e. Dukungan untuk kampanye pemasaran secara langsung.

\subsection{Klasifikasi}

Klasifikasi (Classification) merupakan fungsi data mining yang memberikan item dalam koleksi untuk kategori target atau kelas. Tujuannya adalah memprediksi kelas target secara akurat untuk setiap kasus dalam data. Sebagai contoh, model klasifikasi dapat digunakan untuk mengidentifikasi pemohon pinjaman yang resiko kredit yang rendah, resiko kredit yang sedang, atau resiko kredit yang tinggi[8].

Klasifikasi dimulai dengan kumpulan data di mana tugas dari kelas tersebut sudah dikenal. Sebagai contoh, model klasifikasi yang memprediksi risiko kredit dapat dikembangkan berdasarkan data yang diamati pada pemohon pinjaman selama beberapa periode waktu tertentu. Untuk mendapatkan 
data tersebut, mungkin dapat memulainya dengan melacak riwayat pekerjaan, kepemilikan rumah atau sewa, tahun tinggal, jumlah dan jenis investasi, dan seterusnya. Peringkat kredit akan menjadi target, atribut lainnya akan menjadi prediktor, dan data untuk setiap pelanggan akan merupakan suatu kasus [8].

\subsection{Algoritma C 4.5}

Algoritma c4.5 merupakan algoritma yang dignakan untuk membentuk pohon keputusan [5]. Pohon keputusan merupakan metode klasifikasi dan metode prediksi yang sangat kuat dan terkenal. Metode pohon keputusan mengubah fakta yng sangat besar menjadi pohonkeputusanyng sangat dapat dengan mudah dipahami dengan bahasa alami. Dan mereka juga dapat diekspreikan dalam bentuk bahasa basis data seperti structured query language untuk mencarirecord pada kategori tertentu [5].

Secara umum algoritma C4.5 untuk membangun pohon keputusan adalah sebagai berikut [5]:

1. Pilih atribut sebagai akar

2. Buat cabang untuk masing-masing nilai

3. Bagi kasus dalam cabang

4. Ulangi proses untuk masing-masing cabang sampai semua kasus pada cabang memiliki kelas yang sama.

Untuk perhitungan nilai entrophy dapat dilihat pada persamaan sebagai berikut:

$$
\operatorname{Entropy}(S) \sum_{i=1}^{n}-p i * \log 2 p i
$$

Keterangan :

$\mathrm{S}:$ himpunan kasus

A : fitur

$\mathrm{n}$ : jumlah partisi $\mathrm{S}$

pi : proporsi dari Si terhadap $S$

Untuk memilih atribut sebagai akar, didasarkan pada nilai gain tertinggi dari atribut-atribut yang ada. Untuk menghitung gain digunakan rumus seperti tertera dalam persamaan berikut:

Keterangan :

$$
\operatorname{Gain}(S, A)=\operatorname{Entropy}(S)-\sum_{i=1}^{n} \frac{|s i|}{|s|} * \operatorname{Entropy}(S i)
$$
S : himpunan kasus
A : atribut
$\mathrm{n} \quad$ : jumlah partisi atribut $\mathrm{A}$
$|\mathrm{Si}|$ : jumlah kasus pada partisi ke-i
$|\mathrm{S}|$ : jumlah kasus dalam $\mathrm{S}$

\subsection{Prediksi}

Menurut kamus besar bahasa Indonesia, prediksi adalah hasil dari kegiatan memprediksi atau meramal atau memperkirakan. pengertian prediksi secara istilah akan sangat tergantung pada konteks atau permasalahannya. Berbeda dengan pengertian prediksi secara bahasa yang berarti ramalan atau perkiraaan yang sudah menjadi pengertian yang baku.

Prediksi digunakan untuk memperkirakan nilai masa mendatang, misalnya memprediksi stok barang satu tahun ke depan. Fungsi ini mencakup metode Neural Network, Decision Tree, dan Nearest Neighbor. Prediksi menggunakan beberapa variabel atatu field-field basis data untuk memprediksi nilai-nilai variabel masa mendatang yang diperlukan, yang belum diketahui saat ini. 
Menurut Kusrini dan Emha Taufiq Luthfi, 2009, Di dalam Data Mining, prediksi hampir sama dengan klasifikasi dan estimasi, kecuali bahwa prediksi nilai dari hasil akan ada di masa mendatang [3].

\subsection{Bank Perkreditan Rakyat}

Menurut Herri, dkk, 2007, Sesuai Undang Undang Republik Indonesia No. 7 tahun 1992 tentang Perbankan, sebagaimana telah diubah dengan Undang-Undang No. 10 tahun 1998, BPR adalah bank yang melaksanakan kegiatan usaha secara konvensional atau berdasarkan Prinsip Syariah yang dalam kegiatannya tidak memberikan jasa dalam lalu lintas pembayaran [3].

Menurut Herri, dkk, 2007, Usaha BPR meliputi, menghimpun dana dari masyarakat dalam bentuk simpanan berupa deposito berjangka, tabungan, dan atau bentuk lainnya yang dipersamakan dengan itu; memberikan kredit; menyediakan pembinaan dan penempatan dana berdasarkan Prinsip Syariah sesuai dengan ketentuan yang ditetapkan oleh Bank Indonesia; menempatkan dananya dalam bentuk Sertifikat Bank Indonesia, deposito berjangka, sertifikat deposito dan tabungan pada bank lain [3].

\section{Metodologi}

Agar penelitian ini terarah dan sesuai dengan tujuan yang diharapkan, maka metodologi penelitian yang digunakan adalah sesuai dengan kerangka penelitian berikut ini.

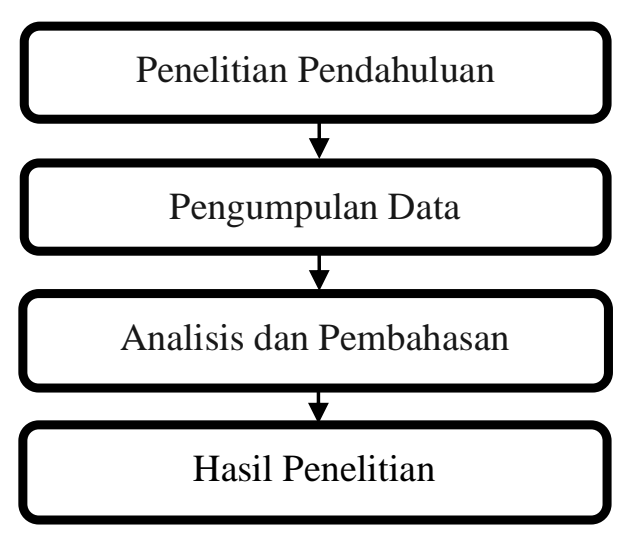

a. Penelitian Pendahuluan

Penelitian pendahuluan merupakan awal dari penelitian, karena pada tahap ini dikumpulkan semua masalah yang terjadi di objek penelitian yaitu Bank Perkreditan Rakyat.

b. Pengumpulan Data

Pengumpulan data dimulai dari pengumpulan literatur yang berhubungan dengan penelitian, kemudian dilanjutkan dengan mendatangi objek penelitian untuk memperoleh sampel data yang akan diolah dengan data mining.

c. Analisa dan Pembahasan

Tahap ini akan mulai dilakukan jika data untuk proses training sudah terkumpul dan akan dimulai proses perhitungan untuk memprediksi keputusan yang akan diambil terkait dengan masalah yang terjadi di objek penelitian.

d. Hasil Penelitian

Hasil dari penelitian ini adalah berupa prediksi dalam pemberian kredit kepada nasabah di Bank Perkreditan Rakyat 
UPI YPTK Jurnal KomTekInfo Vol. 5, No. 1, Juni 2018, Hal. 70-80 ISSN :2356-0010 | eISSN :2502-8758

Copyright@2018 by LPPM UPI YPTK Padang

\section{Analisa dan Hasil Penelitian}

\subsection{Analisa Data}

Penelitian dilakukan di sebuah Bank Perkreditan Rakyat yang ada di Padang. Penelitian ini menggunakan 20 record data nasabah yang melakukan pengajuan kredit di Bank Perkreditan Rakyat tersebut. Data tersebut sudah melalui proses pembersihan dan data 20 record tersebut yang digunakan sebagai data training.

Berikut adalah 20 data training yang digunakan untuk menentukan prediksi jumlah pemberian kredit di Bank Perkreditan Rakyat.

Tabel 1. Data Training

\begin{tabular}{|c|c|c|c|c|c|c|}
\hline Nasabah & Penghasilan & Pekerjaan & Jaminan & Saldo & $\begin{array}{c}\text { Anggota } \\
\text { KK }\end{array}$ & $\begin{array}{c}\text { Keputusan } \\
\text { Jumlah Kredit }\end{array}$ \\
\hline 1 & Menengah & Wiraswasta & Sertifikat & Sedang & Sedikit & Besar \\
\hline 2 & Menengah & Pegawai Negeri & BPKB & Sedang & Sedikit & Besar \\
\hline 3 & Menengah & Pegawai Negeri & BPKB & Banyak & Sedikit & Besar \\
\hline 4 & Rendah & Pekerja Lepas & Barang Elektronik & Sedikit & Sedikit & Kecil \\
\hline 5 & Menengah & Wiraswasta & Barang Elektronik & Sedikit & Sedikit & Kecil \\
\hline 6 & Rendah & Wiraswasta & Barang Elektronik & Sedang & Sedang & Kecil \\
\hline 7 & Menengah & Wiraswasta & Sertifikat & Banyak & Sedang & Besar \\
\hline 8 & Menengah & Wiraswasta & Sertifikat & Sedang & Sedang & Kecil \\
\hline 9 & Menengah & Pegawai Negeri & Sertifikat & Sedang & Sedikit & Kecil \\
\hline 10 & Menengah & Wiraswasta & Sertifikat & Banyak & Sedang & Besar \\
\hline 11 & Menengah & Pegawai Negeri & Sertifikat & Banyak & Sedikit & Besar \\
\hline 12 & Tinggi & Pegawai Negeri & SK & Sedang & Banyak & Kecil \\
\hline 13 & Tinggi & Wiraswasta & SK & Sedang & Sedang & Kecil \\
\hline 14 & Menengah & Pegawai Negeri & SK & Sedang & Sedang & Kecil \\
\hline 15 & Rendah & Pekerja Lepas & Barang Elektronik & Sedikit & Sedang & Kecil \\
\hline 16 & Rendah & Wiraswasta & Barang Elektronik & Sedikit & Sedang & Kecil \\
\hline 17 & Menengah & Wiraswasta & Sertifikat & Sedikit & Sedikit & Kecil \\
\hline 18 & Menengah & Wiraswasta & Sertifikat & Sedang & Sedikit & Besar \\
\hline 19 & Menengah & Wiraswasta & Sertifikat & Sedang & Sedang & Kecil \\
\hline 20 & Menengah & Wiraswasta & Sertifikat & Sedikit & Sedang & Kecil \\
\hline
\end{tabular}

Data penentuan jumlah pemberian kredit di Bank Perkreditan Rakyat terdiri dari 6 atribut, dimana 5 atribut prediktor dan 1 atribut label, seperti yang ditunjukkan pada tabel berikut :

Tabel 1. Daftar atribut prediktor dan klasifikasinya

\begin{tabular}{|c|c|c|c|}
\hline No & Atribut & Nilai Atribut & Klasifikasi \\
\hline \multirow{3}{*}{1} & \multirow{3}{*}{$\begin{array}{l}\text { Penghasilan } \\
\text { Nasabah }\end{array}$} & Penghasilan > Rp. 5.000.000,- & Tinggi \\
\hline & & Rp. 2.000.000,- $\leq$ Penghasilan $\leq$ Rp. 5.000.000,- & Menengah \\
\hline & & Penghasilan < Rp. 2.000.000,- & Rendah \\
\hline \multirow{3}{*}{2} & \multirow{3}{*}{ Pekerjaan } & PNS, ABRI, POLISI & Pegawai Negeri \\
\hline & & Wiraswasta, Pedagang & Wiraswasta \\
\hline & & Petani, Office Boy & Pekerja Lepas \\
\hline
\end{tabular}


UPI YPTK Jurnal KomTekInfo Vol. 5, No. 1, Juni 2018, Hal. 70-80 ISSN :2356-0010 | eISSN :2502-8758 Copyright@2018 by LPPM UPI YPTK Padang

\begin{tabular}{|c|c|c|c|}
\hline \multirow{4}{*}{3} & \multirow{4}{*}{ Jaminan } & SK Jabatan & SK \\
\hline & & Sertifikat Rumah, Sertifikat Tanah & Sertifikat \\
\hline & & BPKB Kendaraan Roda 4, BPKB Kendaraan Roda 2 & BPKB \\
\hline & & Elektronik & Barang Elektronik \\
\hline \multirow{3}{*}{4} & \multirow{3}{*}{$\begin{array}{l}\text { Saldo di } \\
\text { Rekening } \\
\text { Nasabah }\end{array}$} & Saldo > Rp.10.000.000 & Banyak \\
\hline & & Rp. 5.000.000,- $\leq$ Saldo $\leq$ Rp.10.000.000,- & Sedang \\
\hline & & Saldo < Rp.5.000.000,- & Sedikit \\
\hline \multirow{3}{*}{5} & \multirow{3}{*}{$\begin{array}{l}\text { Anggota } \\
\text { Kartu } \\
\text { Keluarga }\end{array}$} & $<4$ Orang & Sedikit \\
\hline & & 4 Orang s/d 7 Orang & Sedang \\
\hline & & $>7$ Orang & Banyak \\
\hline
\end{tabular}

Tabel 2. Klasifikasi atribut

\begin{tabular}{|l|l|l|}
\hline No & \multicolumn{1}{|c|}{ Atribut } & \multicolumn{1}{c|}{ Klasifikasi } \\
\hline \multirow{2}{*}{1} & $\begin{array}{l}\text { Jumlah Pemberian } \\
\text { Kredit }\end{array}$ & Besar \\
\cline { 3 - 3 } & & Kecil \\
\hline
\end{tabular}

\subsection{Analisa Proses}

Dari pengelompokkan atribut diatas, maka langkah selanjutnya adalah melakukan analisa proses dalam data mining dengan menggunakan Algoritma C 4.5.

Untuk membuat pohon keputusan, harus ditentukan terlebih dahulu nilai Entropy untuk masingmasing atribut prediktor dan nilai Gain untuk masing-masing prediktor untuk mendapatkan atribut akar.

Tabel 3. Hasil perhitungan Node 1

\begin{tabular}{|l|l|l|c|c|c|c|c|}
\hline \multirow{2}{*}{ NODE } & & & $\begin{array}{c}\text { Jml Kasus } \\
(\mathrm{S})\end{array}$ & $\begin{array}{c}\text { Besar } \\
\left(\mathrm{S}_{1}\right)\end{array}$ & $\begin{array}{c}\text { Kecil } \\
\left(\mathrm{S}_{3}\right)\end{array}$ & Entropy & Gain \\
\hline 1 & TOTAL & & 20 & 7 & 13 & 0,934 & \\
\hline & Penghasilan & & & & & & 0,234 \\
\hline & & Tinggi & 2 & 0 & 2 & 0,000 & \\
\hline & & Menengah & 14 & 7 & 7 & 1,000 & \\
\hline & & Rendah & 4 & 0 & 4 & 0,000 & \\
\hline & Pekerjaan & & & & & & 0,083 \\
\hline & & Pegawai Negeri & 6 & 3 & 3 & 1,000 & \\
\hline & & Wiraswasta & 12 & 4 & 8 & 0,918 & \\
\hline & & Pekerja Lepas & 2 & 0 & 2 & 0,000 & \\
\hline & Jaminan & & & & & & 0,434 \\
\hline & & Sertifikat & 10 & 5 & 5 & 1,000 & \\
\hline & & BPKB & 2 & 2 & 0 & 0,000 & \\
\hline & & SK & 3 & 0 & 3 & 0,000 & \\
\hline & & Barang Elektronik & 5 & 0 & 5 & 0,000 & \\
\hline & Saldo & Banyak & 4 & 4 & 0 & 0,000 & \\
\hline & & Sedang & 10 & 3 & 7 & 0,881 & \\
\hline & & Sedikit & 6 & 0 & 6 & 0,000 & \\
\hline
\end{tabular}


UPI YPTK Jurnal KomTekInfo Vol. 5, No. 1, Juni 2018, Hal. 70-80 ISSN :2356-0010 | eISSN :2502-8758 Copyright@2018 by LPPM UPI YPTK Padang

\begin{tabular}{|l|l|l|c|c|c|c|c|} 
& & & & & & 0,127 \\
\hline & Anggota KK & & 1 & 0 & 1 & 0,000 & \\
\hline & & Banyak & 10 & 2 & 8 & 0,722 & \\
\hline & & Sedang & 9 & 5 & 4 & 0,991 & \\
\hline
\end{tabular}

Dari tabel diatas, dapat dilihat Saldo mempunyai nilai Gain tertinggi sehingga Saldo menjadi akar dari pohon keputusan yang akan dibuat. Untuk memperoleh cabang dari akar tersebut, maka dilakukan perhitungan di node 2 .

Tabel 4. Hasil perhitungan Node 2

\begin{tabular}{|c|c|c|c|c|c|c|c|}
\hline NODE & & & $\begin{array}{c}\text { Jml Kasus } \\
\text { (S) }\end{array}$ & $\begin{array}{c}\text { Besar } \\
\left(S_{1}\right)\end{array}$ & $\begin{array}{c}\text { Kecil } \\
\left(S_{3}\right)\end{array}$ & Entropy & Gain \\
\hline \multirow[t]{18}{*}{1.1} & Saldo & Sedang & 10 & 3 & 7 & 0,881 & \\
\hline & Penghasilan & & & & & & 0,192 \\
\hline & & Tinggi & 2 & 0 & 2 & 0,000 & \\
\hline & & Menengah & 7 & 3 & 4 & 0,985 & \\
\hline & & Rendah & 1 & 0 & 1 & 0,000 & \\
\hline & Pekerjaan & & & & & & 0,006 \\
\hline & & Pegawai Negeri & 4 & 1 & 3 & 0,811 & \\
\hline & & Wiraswasta & 6 & 2 & 4 & 0,918 & \\
\hline & & Pekerja Lepas & 0 & 0 & 0 & 0,000 & \\
\hline & Jaminan & & & & & & 0,396 \\
\hline & & Sertifikat & 5 & 2 & 3 & 0,971 & \\
\hline & & BPKB & 1 & 1 & 0 & 0,000 & \\
\hline & & SK & 3 & 0 & 3 & 0,000 & \\
\hline & & Barang Elektronik & 1 & 0 & 1 & 0,000 & \\
\hline & Anggota KK & & & & & & $\mathbf{0 , 5 5 7}$ \\
\hline & & Banyak & 1 & 0 & 1 & 0,000 & \\
\hline & & Sedang & 5 & 0 & 5 & 0,000 & \\
\hline & & Sedikit & 4 & 3 & 1 & 0,811 & \\
\hline
\end{tabular}

Dari tabel diatas, dapat dilihat Jumlah Anggota KK mempunyai nilai Gain tertinggi sehingga Anggota KK menjadi cabang pertama dari pohon keputusan yang akan dibuat. Untuk memperoleh cabang berikutnya, maka dilakukan perhitungan di node 3 .

Tabel 5. Hasil perhitungan Node 3

\begin{tabular}{|l|l|l|c|c|c|c|c|}
\hline NODE & & $\begin{array}{c}\text { Jml Kasus } \\
(\mathrm{S})\end{array}$ & $\begin{array}{c}\text { Besar } \\
\left(\mathrm{S}_{1}\right)\end{array}$ & $\begin{array}{c}\text { Kecil } \\
\left(\mathrm{S}_{3}\right)\end{array}$ & Entropy & Gain \\
\hline 1.1 .1 & Anggota KK & Sedikit & 4 & 3 & 1 & 0,811 & \\
\hline & Penghasilan & & & & & & 0,000 \\
\hline & & Tinggi & 0 & 0 & 0 & 0,000 & \\
\hline & & Menengah & 4 & 3 & 1 & 0,811 & \\
\hline & & Rendah & 0 & 0 & 0 & 0,000 & \\
\hline & Pekerjaan & & & & & & $\mathbf{0 , 3 1 1}$ \\
\hline & & Pegawai Negeri & 2 & 1 & 1 & 1,000 & \\
\hline & & Wiraswasta & 2 & 2 & 0 & 0,000 & \\
\hline & & Pekerja Lepas & 0 & 0 & 0 & 0,000 & \\
\hline
\end{tabular}


UPI YPTK Jurnal KomTekInfo Vol. 5, No. 1, Juni 2018, Hal. 70-80 ISSN :2356-0010 | eISSN :2502-8758 Copyright@2018 by LPPM UPI YPTK Padang

\begin{tabular}{|l|l|l|l|l|l|l|l|} 
& Jaminan & & & & & & 0,123 \\
\hline & & Sertifikat & 3 & 2 & 1 & 0,918 & \\
\hline & & BPKB & 1 & 1 & 0 & 0,000 & \\
\hline & & SK & 0 & 0 & 0 & 0,000 & \\
\hline & & Barang Elektronik & 0 & 0 & 0 & 0,000 & \\
\hline
\end{tabular}

Dari tabel diatas, dapat dilihat Pekerjaan mempunyai nilai Gain tertinggi sehingga Pekerjaan menjadi cabang kedua dari pohon keputusan yang akan dibuat. Untuk memperoleh cabang berikutnya, maka dilakukan perhitungan di node 4 .

Tabel 6. Hasil perhitungan Node4

\begin{tabular}{|l|l|l|c|c|c|c|c|}
\hline NODE & & $\begin{array}{c}\text { Jml Kasus } \\
(\mathrm{S})\end{array}$ & $\begin{array}{c}\text { Besar } \\
\left(\mathrm{S}_{1}\right)\end{array}$ & $\begin{array}{c}\text { Kecil } \\
\left(\mathrm{S}_{3}\right)\end{array}$ & Entropy & Gain \\
\hline 1.1 & Pekerjaan & Pegawai Negeri & 2 & 1 & 1 & 1,000 & \\
\hline & Penghasilan & & & & & & 0,000 \\
\hline & & Tinggi & 0 & 0 & 0 & 0,000 & \\
\hline & & Menengah & 2 & 1 & 1 & 1,000 & \\
\hline & & Rendah & 0 & 0 & 0 & 0,000 & \\
\hline & Jaminan & & & & & & $\mathbf{1 , 0 0 0}$ \\
\hline & & Sertifikat & 1 & 0 & 1 & 0,000 & \\
\hline & & BPKB & 1 & 1 & 0 & 0,000 & \\
\hline & & SK & 0 & 0 & 0 & 0,000 & \\
\hline & & Barang Elektronik & 0 & 0 & 0 & 0,000 & \\
\hline
\end{tabular}

Dari tabel diatas, dapat dilihat Jaminan mempunyai nilai Gain tertinggi sehingga Jaminan menjadi cabang ketiga dari pohon keputusan dan merupakan cabang terakhir. Sehingga diperoleh pohon keputusan seperti berikut :

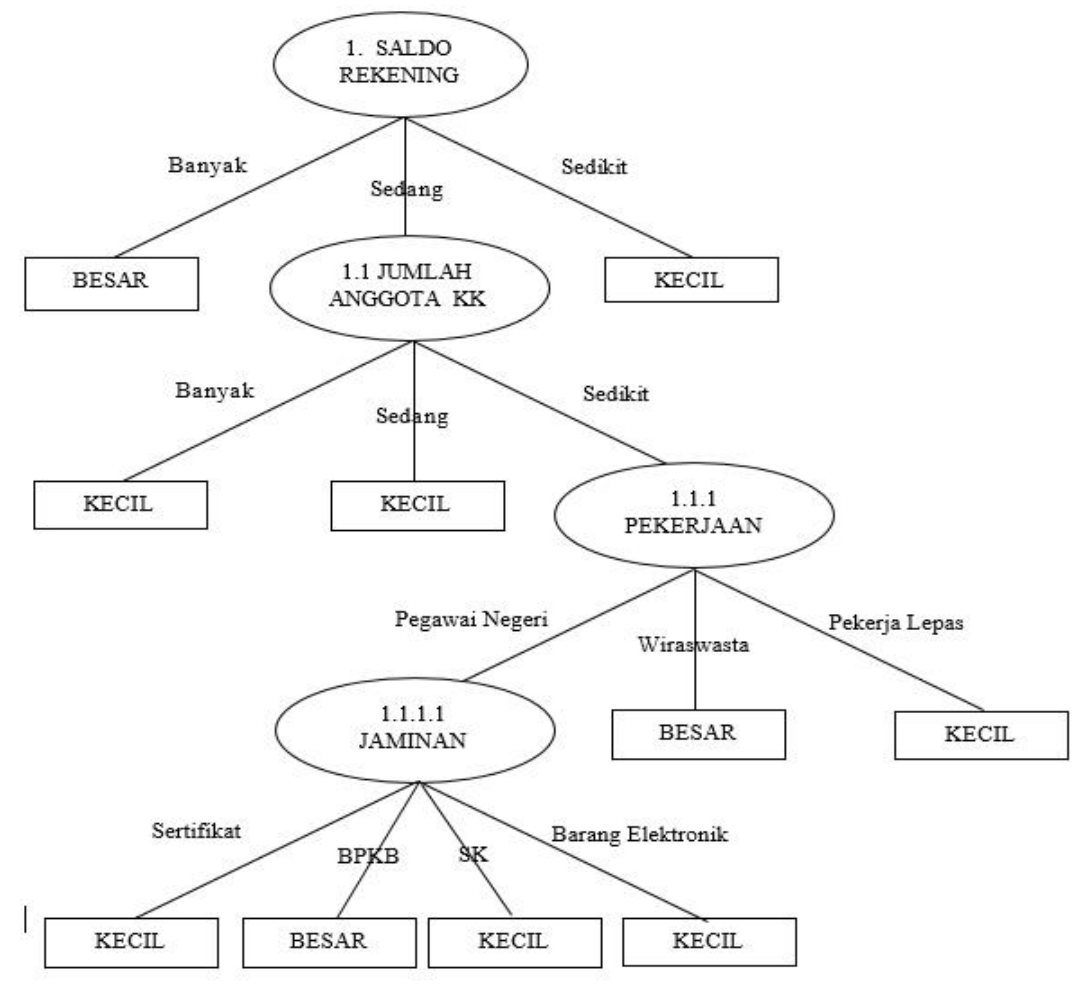

Gambar 2. Pohon Keputusan Prediksi Pemberian Jumlah Kredit 
Dapat dilihat pohon keputusan yang dihasilkan dari 20 data training nasabah yang digunakan pada gambar diatas. Pohon keputusan ini bisa digunakan untuk pengambilan keputusan dalam penentuan jumlah kredit, jika ada nasabah baru yang ingin mengajukan kredit.

Misalnya diketahui data nasabah baru seperti berikut yang digunakan sebagai data testing :

Tabel 7. Data Nasabah Baru

\begin{tabular}{|c|c|c|c|c|c|c|}
\hline $\begin{array}{c}\text { Nasabah } \\
\text { ke }\end{array}$ & Penghasilan & Pekerjaan & Jaminan & Saldo & Anggota KK & $\begin{array}{c}\text { Keputusan } \\
\text { Jumlah } \\
\text { Kredit }\end{array}$ \\
\hline 21 & $\begin{array}{c}\text { Rp. } \\
3.500 .000,-\end{array}$ & PNS & $\begin{array}{c}\text { BPKB Kendaraan } \\
\text { Roda 2 }\end{array}$ & $\begin{array}{c}\text { Rp. } \\
8.300 .000,-\end{array}$ & 3 Orang & ??? \\
\hline
\end{tabular}

Data dari nasabah baru diatas harus diklasifikasikan terlebih dahulu menjadi seperti berikut :

Tabel 8. Data Testing Nasabah Baru

\begin{tabular}{|c|c|c|c|c|c|}
\hline $\begin{array}{c}\text { Nasabah } \\
\text { ke }\end{array}$ & Penghasilan & Pekerjaan & Jaminan & Saldo & Anggota KK \\
\hline 21 & Menengah & Pegawai Negeri & BPKB & Sedang & Sedikit \\
\hline
\end{tabular}

Dari data testing diatas, dapat diperoleh sebuah keputusan dengan melihat pohon keputusan yang sudah dihasilkan diatas. Jadi keputusan yang dapat diambil dari data testing diatas untuk pemberian jumlah kredit pada nasabah ke-21 adalah BESAR.

\section{Kesimpulan}

Dari hasil penelitian, maka dapat diambil beberap kesimpulan, diantaranya :

1. Proses prediksi pemberian kredit di Bank Perkreditan Rakyat dapat dilakukan dengan menggunakan data mining. Metode yang digunakan adalah metode klasifikasi data, salah satunya adalah Algoritma C 4.5

2. Penelitian ini sudah dapat membantu Bank Perkreditan Rakyat dalam memprediksi pemberian kredit dengan bantuan analisa data mining.

3. Penelitian ini masih bersifat analisa, diharapkan pada penelitian selanjutnya bisa dihasilkan sebuah aplikasi yang terintegrasi langsung dengan data Bank Perkreditan Rakyat, sehingga proses prediksi dapat dilakukan kapan pun.

\section{Referensi}

[1] Gorunescu, Florin, "Data.Mining Concepts Models and Techniques". Springer,.2011

[2] Dua, Sumeet and Xian Du, "Data Mining and Machine Learning in Cybersecurity". CRC Press, 2011.

[3] Mandala, Eka Praja Wiyata, Data Mining Algoritma Nearest Neighbor Untuk Memprediksi Tingkat Resiko Pinjaman Dana Di Bank Perkreditan Rakyat, Jurnal Ilmu Komputer., 2016

[4] Wahono, Romi Satria, "Data Mining Introduction"., 2012

[5] Kusrini., dan Emha Taufik Luthfi, Algoritma Data Mining, Penerbit Andi, 2008

[6] Han, Jiawei and Micheline Kamber, "Data Mining Concepts and Techniques Third Edition", Elsevier, 2011

[7] Larose, Daniel T, "Discovering Knowledge in Data an Introduction to Data Mining", John Wiley \& Sons, 2005

[8] Oracle, Oracle Data Mining Concept 11g Release 1(11.1), Oracle., 2008

[9] Fayyad, Usama M, Gregory Piatetsky-Shapiro, Padhraic Smyth, Ramasamy Uthurusamy, "Advances in Knowledge Discovery and Data Mining”, MIT Press, 1996

[10] Turban, Efraim, Jay E. Aronson, Ting-Peng Liang, "Decision Support Systems and Intelligent Systems Seventh Edition", Prentice Hall, 2005 
UPI YPTK Jurnal KomTekInfo Vol. 5, No. 1, Juni 2018, Hal. 70-80 ISSN :2356-0010 | eISSN :2502-8758

Copyright@2018 by LPPM UPI YPTK Padang

[11] Witten, Ian H., Frank Eibe, Mark A. Hall, Data mining Practical Machine Learning Tools and Techniques 3rd Edition, Elsevier,. 2011

[12] Priyadharsini.C, Dr. Antony Selvadoss Thanamani., An Overview of Knowledge Discovery Database and Data mining Techniques, India., 2014

[13] Putra, Dede Wira Trise, Algoritma C4.5 Untuk Menentukan Tingkat Kelayakan Motor Bekas Yang Akan Dijual, Jurnal TeknoIF, 2016

[14] Mandala, Eka Praja Wiyata., Rahmatino, Aplikasi Data Mining Untuk Memprediksi Kelulusan Siswa Jurusan IPA MAN 3 Padang, Majalah Ilmiah UPI YPTK, 2013

[15] Seema Sharma, Jitendra Agrawal, Sanjeev Sharma., Classification Through Machine Learning Technique: C4.5 Algorithm based on Various Entropies, India., 2013

[16] Mandala, Eka Praja Wiyata., Penerapan Algoritma C 4.5 Dalam Memperoleh Decision Tree Untuk Memprediksi Penentuan Resiko Kredit Pada Bank BPR Bukittandang Mandiri Padang Menggunakan Estard Data Miner, Majalah Ilmiah UPI YPTK, 2013

[17] Putri, Dewi Eka., Metode Non Hierarchy Algoritma K-Means Dalam Mengelompokkan Tingkat Kelarisan Barang (Studi Kasus: Koperasi Keluarga Besar Semen Padang), Prosiding Senatkom, 2015 